

IZADP No. 2917

The Impact of Teams on Output, Quality and Downtime: An Empirical Analysis Using Individual Panel Data

Derek C. J ones

Takao Kato

J uly 2007 


\title{
The Impact of Teams on Output, Quality and Downtime: An Empirical Analysis Using Individual Panel Data
}

\author{
Derek C. Jones \\ Hamilton College, WDI and SKOPE \\ Takao Kato \\ Colgate University, Columbia Business School, \\ Tokyo Center for Economic Research, \\ Aarhus School of Business and IZA
}
Discussion Paper No. 2917
July 2007

IZA

P.O. Box 7240

53072 Bonn

Germany

\author{
Phone: +49-228-3894-0 \\ Fax: +49-228-3894-180 \\ E-mail: iza@iza.org
}

\begin{abstract}
Any opinions expressed here are those of the author(s) and not those of the institute. Research disseminated by IZA may include views on policy, but the institute itself takes no institutional policy positions.

The Institute for the Study of Labor (IZA) in Bonn is a local and virtual international research center and a place of communication between science, politics and business. IZA is an independent nonprofit company supported by Deutsche Post World Net. The center is associated with the University of Bonn and offers a stimulating research environment through its research networks, research support, and visitors and doctoral programs. IZA engages in (i) original and internationally competitive research in all fields of labor economics, (ii) development of policy concepts, and (iii) dissemination of research results and concepts to the interested public.
\end{abstract}

IZA Discussion Papers often represent preliminary work and are circulated to encourage discussion. Citation of such a paper should account for its provisional character. A revised version may be available directly from the author. 


\section{ABSTRACT}

\section{The Impact of Teams on Output, Quality and Downtime: An Empirical Analysis Using Individual Panel Data*}

To investigate the size and the timing of the direct impact of participatory arrangements on business performance, we assemble and analyze extraordinary daily data - for rejection, production and downtime rates for all operators in a single plant during a 35 month period, more than 77,000 observations. Consistent with core hypotheses that employee involvement enhances productivity and quality through mechanisms including employees becoming better motivated, more informed and paying greater attention to product details, we find that membership in offline teams: (i) initially enhances individual productivity by about 3\%; (ii) and lowers rejection rates by about $27 \%$. We also find that: (iii) these improvements are dissipated, typically at 10 to $16 \%$ per 100 days in a team; (iv) while initially teams lead to more downtime, these costs diminish over time; (v) the performance-enhancing effects of team membership are generally greater and more long-lasting for team members who are solicited by management; and (vi) similar relationships exist for more educated team members. These findings square with diverse hypotheses concerning predicted gains from complementarities in organizational design, the benefits that flow from management solicitation and enhanced education, but are inconsistent with hypotheses based on Hawthorne effects.

JEL Classification: $\quad$ M54, J50, J41, D20

Keywords: teams, employee involvement, productivity, quality, econometric case study

Corresponding author:

Takao Kato

Department of Economics

Colgate University

13 Oak Drive

Hamilton, NY 13346

USA

E-mail: tkato@mail.colgate.edu

\footnotetext{
The paper has benefited from suggestions from participants at seminars and conferences at Hitotsubashi, Oxford, Tokyo, Kyoto, Osaka, Hosei, the Institute of Statistical Research, Union College, Helsinki School of Economics, New South Wales, Wesleyan, Cornell, Upjohn Institute, Washington, San Francisco, Bavaria, Illinois at Urbana-Champaign, UBC, and Simon Fraser. Grant and Fellowship support from the Russell Sage/Rockefeller Foundation Future of Work Program, NSF (SES-0522118), the Institute of Innovation Research at Hitotsubashi, Tokyo and the Abe Fellowship Program are gratefully acknowledged.
} 


\section{Introduction}

\section{The Impact of Teams on Output, Quality and Downtime: An Empirical Analysis Using Individual Panel Data}

In many areas of economics the gains from advances in econometric techniques and theory have been muted because of limited data (Griliches, 1994:2). This proposition applies especially forcefully in the literature concerning the nature and effects of human resource policies. While much theoretical work points to the existence of powerful links between business performance and workplace innovations, especially high performance workplace practices (HPWPs) such as employee involvement and incentive pay, often theorists disagree over the size, direction and nature of such links. ${ }^{1}$ Moreover, in attempting to assess recent theoretical advances in this area, most empirical work necessarily has used data from national surveys of firms or establishments from diverse industries (e.g. on firm-level outcomes see Craig and Pencavel, 1995; Appelbaum and Batt, 1994; Jones and Kato, 1995; Freeman, Kleiner and Ostroff, 2000.) $)^{2}$ Unfortunately, while such studies are very valuable, potentially national crossindustry studies have significant limitations including measurement problems, endogeneity, and omitted variables (e.g. Bartel, Ichniowski and Shaw, 2004).

One important response to these difficulties of national cross-industry studies has been "insider econometric studies" in which researchers conduct detailed qualitative field research at establishments within a narrowly defined industry and develop detailed understanding of the actual production process and the use of HPWPs. Researchers then obtain access to unique internal and confidential data at the level of establishments or branches (e.g., physical

\footnotetext{
${ }^{1}$ Compare, for example, Alchian and Demsetz (1972), with Holmstrom and Milgrom, 1995. See also for example Kandel and Lazear (1992), Gibbons (1997) and Prendergast (1999) who provide insightful surveys of the theoretical literature.

${ }^{2}$ On establishment-level outcomes see for example Black and Lynch (2001) and Cappelli and Neumark (2001). Most international studies are also of this type. For instance, see Kato and Morishima (2002) for Japan; Addison and Belfield (2000), Freeman and Conyon (2001), DeVaro (2004) for the U.K.; Caroli and Van Reenen (2001) for France; Eriksson (2003) for Denmark; Bayo-Moriones, Galilea-
} 
productivity, rejection rate and downtime at the establishment-level) and estimate the impact on establishment performance of HPWPs (e.g., Ichniowski, Shaw and Prennushi, 1997). ${ }^{3}$

Another important development is empirical work by economists that uses data on individual workers employed by a single firm (e.g. Hamilton, Nickerson and Owan, 2003; Lazear, 2000). ${ }^{4}$ These "econometric case studies" allow one to incorporate more detailed information on key features of the organization of production than is possible using traditional data for a large number of firms. Thus they go deep within the "black-box" of the firm and enable one to obtain more precise estimates of the effects of HPWPs on firms and employees and the channels through which these practices operate. However, since such data are notoriously difficult to obtain there have only been a handful of such "insider econometric" studies. It is to this latter class of work that this paper makes several contributions.

Specifically, we provide the first rigorous empirical analysis of the economic effects of employee involvement in teams in a plant that had only recently introduced offline teams and where not all workers were team members. We make use of a unique data set that has been constructed for this case during a period of thirty-five months. Our data are for all operators in that plant during that period and include all workers who remain in the plant as well as workers who leave the firm. For these operators we have daily observations for key measures of individual performance, specifically measures of individual physical production and rejection rates for individual worker output. Also we are able to use data on individual rates of downtime. These data enable us to meet the demanding data requirements that are necessitated by

Salvatierra, Merino-Díaz de Cerio ((2003) for Spain; Leoni, et al. (2003) for Italy; and Zwick (2004) for Germany.

${ }^{3}$ See also MacDuffie (1995), Dunlop and Weil (1996), Kelley (1996), Huselid and Becker (1996), Helper (1998), Bartel (2004), and Appelbaum et al. (2000). Ichniowski, et al. (1996) provide a succinct discussion on the key methodological issues encountered by empirical studies.

${ }^{4}$ Pioneering works using internal personnel data in economic research include Medoff and Abraham (1980), and Baker, Gibbs, and Holmstrom (1994a, 1994b). 
institutionally informed econometric case studies. ${ }^{5}$ These extraordinary data enable us to provide rigorous empirical tests of diverse hypotheses including the direct impact of membership in offline teams on production and quality.

Our interest in teams in part reflects the changing nature of workplaces during the last thirty years or so. A notable feature is the emergence of HPWPs including mechanisms that provide for employee involvement (e.g. teams, quality circles, total quality management, and information sharing) and incentive pay (e.g. profit sharing and employee stock ownership). ${ }^{6}$ Particular attention has been paid to the use of various kinds of teams. While estimates of the incidence of teams vary, there is agreement that there has been a dramatic increase in the use of employee involvement through mechanisms including teams in US industry. The structure of the paper is as follows.

In the next section we briefly provide a conceptual review and develop the six hypotheses we test in our empirical work. This is followed by a review of relevant econometric case study evidence. To provide adequate institutional context for our statistical analysis, we then provide a detailed discussion of key institutional features for our case. We also discuss our data and provide descriptive statistics for key variables. The main parts of our paper are contained in the penultimate section where we present our empirical strategy and findings.

A key finding is that membership in offline teams results in modest but nevertheless significant enhanced individual rates of output. More dramatic effects are found for product quality as participation in offline teams leads to large falls in rejection rates. Evidence is also found that the introduction of teams is initially accompanied by significant costs in the form of increased rates of downtime, though these costs dissipate over time. All of our findings are

\footnotetext{
${ }^{5}$ For a recent review of such studies see Jones, Kalmi and Kauhanen (2006).

${ }^{6}$ For estimates of the incidence of teams in the U.S., based on establishment-level surveys, see for example Osterman (1994), and Black and Lynch (2004). For estimates of the team incidence based on
} 
insensitive to including/excluding operators who left during the study period. Consistent with theorists who stress the benefits of complementarities in organizational design, we find that the impact of enhanced employee involvement through teams alone is not sustained at initial levels.

Our data also enable us to investigate issues concerning the team member selection process and the possible complementary role of education in team effects. When we examine team effects separately for those solicited by management and those who volunteered to become team members without management solicitation, we find that the performance-enhancing effects of team membership tend to be greater and more long-lasting for solicited team members and that the cost (or increased downtime) of team membership is smaller and diminishes more quickly for solicited team members. The finding is consistent with our conjectures: (i) that management will have a better sense of those individuals who are both likely to be better fits as team members and also more likely to continue to be motivated and to learn skills in teams; (ii) that some of those employees who volunteer to become team members without management solicitation may be behaving opportunistically; and (iii) that management solicitation serves as a credible signal to the solicited workers that they are indeed in the promotion tournament for line supervisors. Turning to education, when we study whether the performance effects of team membership differ between those with and without education beyond high school, we find that the performance-enhancing effects of teams (especially quality improvement) are generally greater and more long-lasting for team members with education beyond high school. This evidence suggests a complementarity between teams and formal education.

firm-level surveys in the U.S., see for example Freeman, Kleiner and Ostroff (2000). For estimates based on worker surveys in the U.S., see for example Freeman and Rogers (1999). 


\section{Conceptual Framework and Hypotheses}

To develop our two core hypotheses on the expected association between employee involvement and ultimately firm performance, we briefly review key aspects of the theoretical debate especially literature that focuses on employee participation via membership in teams. Since ours is not a theoretical contribution and good reviews of this literature already exist, ${ }^{7}$ here we merely highlight themes in the debates. First, however, we note that the theoretical literature sometimes does not clearly recognize that "teams" may assume various organizational forms. For the most part, theorists implicitly appear to assume that teams are on-line (such as "cells" in many US companies) and not of an off-line character (such as, in many U.S. firms, crossfunctional project teams, task forces, committees and problem solving groups or shop floor committees and joint labor-management committees in Japan or works councils in Germany. $)^{8}$

Our central concern is with the direct impact of employee involvement through teams on business performance. Theorists disagree both as to the expected impact of teams on individual, group and ultimately firm performance as well as concerning the main drivers in these relationships. For those who see teams as having largely beneficial effects for firms (and possibly workers), it is often argued that teams are required because of other developments, notably the remarkable changes in information and communication technologies and the intensification of competition in product markets that increasingly are globalized. These changes mean that firms are better able to manage inventory and, in turn, suggest that there will be bigger payoffs to complementary changes in work organization and quality practices. In particular it is expected that there will be benefits to firms to encourage and reward programs that facilitate more horizontal co-ordination (Milgrom and Roberts, 1995) among workers and produce

\footnotetext{
${ }^{7}$ See for example Gibbons (1997), Gibbons and Waldman (1999), and Prendergast (1999).

${ }^{8}$ For discussions of various participatory arrangements in Japan see Kato (2003).
} 
improved communications among workers so that they can better solve problems. ${ }^{9}$ In this view, as the extent of horizontal co-ordination grows, this produces a need for structural changes within organizations that provide even greater opportunities for enhanced participation, such as teams and financial incentive systems that better link enterprise performance with the involvement of broader groups of workers than just top managers.

One broad group of beneficial outcomes that such arrangements are expected to produce are the direct impact of teams resulting from improved motivation and enhanced discretionary effort by team members and enhanced skill and knowledge of team members. By participating in teams, team members suffer less from information asymmetry, and develop more trust in management, stronger commitment to the organization and their goals are more aligned with the firm's. The result is improved motivation and enhanced discretionary effort among team members. Moreover, team members engage in knowledge sharing among themselves, enhance their human capital and thus the performance of team members improves.

Furthermore, we expect improved performance as a result of teams to be felt more strongly in product quality than in productivity. ${ }^{10}$ The introduction of participatory arrangements in general and offline teams in particular is expected to change employee attitudes so that team members better understand the crucial importance of quality for organizational success. Others argue that the introduction of or membership in teams will foster and enhance trust which has been identified as a key component of successful business systems (see, e.g., Ben-Ner and Putterman, 2003). In turn this is expected to lead to discernible differences in the nature and extent of the care and attention that team participants devote to their jobs and ultimately produce improvements in quality control.

\footnotetext{
${ }^{9}$ Note that this view stands in sharp contrast to arrangements in the traditional vertically organized firm (as modeled by theorists such as Alchian and Demsetz, 1972).

${ }^{10}$ A similar hypothesis was developed for call center workers by Batt (1999).
} 
The principal argument made by those who are more pessimistic as to the impact of teams upon firm performance is that teams may promote free riding by some team members (Alchian and Demsetz, 1972). While this point is deserving of careful attention in many circumstances, arguably this argument is less persuasive when workers participate in crossfunctional off-line teams rather than on-line teams. Furthermore, since in most business organizations the economic game is repeated, then the incentives for all team members to engage in peer monitoring are strengthened.

Consequently the first of our two core hypotheses is whether the introduction of offline teams leads to behavioral changes (such as workers becoming more motivated, better informed, more resourceful, and more inventive) and, in turn, whether this produces measurable differences in discretionary effort and thus individual production of team members. A second and related hypothesis is whether this organizational innovation produces employees who better understand the crucial importance of quality for organizational success, resulting in differences in the care and attention that individuals devote to their jobs, and ultimately producing improvements in quality control by team members?

In the bulk of the remainder of this section we briefly review the theoretical literature to develop four other hypotheses concerning team members. The first of these concerns the extent and the time profile of those organizational costs that may accompany the introduction of various forms of participation. In the case of offline teams, the key costs are the opportunity costs incurred when team members attend team meetings during regular hours. ${ }^{11}$ It is important to investigate hypotheses that bear on the extent and the time profile of these costs. Does the introduction of teams lead to opportunistic behavior by team members (who do not forego

\footnotetext{
${ }^{11}$ Though offline teams in Japanese firms (such as celebrated QC circles) traditionally meet after regular hours with only limited or no compensation, offline teams in U.S. firms normally meet during regular hours. Thus the opportunity costs of offline teams are particularly important for U.S. firms. See Kato (2003) for offline teams in Japanese firms.
} 
compensation when attending meetings) leading to downtime growing over time (as teams become a vehicle for more opportunistic behavior by team members)? Or is it the case that team members do not engage in such opportunistic activities and that they become more efficient at conducting and implementing team business over time. Following Levine and Tyson (1990), our third hypothesis is that the introduction of participatory practices must be viewed as an investment by the firm. This organizational innovation is expected to be accompanied by some initial set-up and learning costs and increased downtime. But our expectation is that these costs will be dissipated over time, if teams function well.

The fourth set of hypotheses to be tested concern the time profile of the impact of teams on business performance. Some theoretical and empirical literature suggests that an individual change in organizational design is expected to be sufficient to produce sustained benefits to the firm. ${ }^{12}$ By contrast other literature argues that, for sustained benefits, complementary measures are needed. An individual initiative when introduced alone may be insufficient to lead to persistent gains. For example, employees might need more sharing of enterprise rewards through financial participation, such as profit sharing, gainsharing and employee stock ownership to accompany teams lest their commitment to teams becomes undermined (Milgrom and Roberts, 1995, Ben-Ner and Jones, 1995, Kato and Morishima, 2002, and Boning, Ichniowski, and Shaw, 2005). The QC circle literature often reports that the productivity-enhancing effects of QC circles introduced by U.S. firms in 1980s has proved to be short-lived since QCs lacked a complementary mechanism to delegate power to front-line workers (e.g., Lawler III, 1986, Griffin, 1988, Kochan and Osterman, 1994, Levine, 1995).

An alternative explanation of the short-lived nature of the productivity effect of teams is that it is a Hawthorne effect. ${ }^{13}$ According to this line of reasoning, team members regard

\footnotetext{
${ }^{12}$ See for example reviews in Blinder (1990) and in Blair and Kochan (2000).

${ }^{13}$ See, for instance, Batt (1999) for a discussion of Hawthorne effects and teams.
} 
themselves as special or they receive individual attention from management. Consequently, better performance does not flow from team membership per se, but rather from the special feelings felt by team members who are given unusual attention. However, such novelty tends to wear away over time and thus the performance improvement is expected to be short-lived.

Our fifth hypothesis concerns a possible difference in team effects between employees who become team members after solicitation by management, compared to those who volunteer to become team members without management encouragement. We hypothesize that the performance-enhancing effects of team membership will be greater and more long-lasting for solicited members than for unsolicited members. Moreover, the cost of team membership (increased downtime) will be smaller and diminish more rapidly as team members engage in learning by doing. We conjecture that this difference may arise in part because skilful personnel managers will have a better sense of those individuals who likely will be both better fits as team members and also are more likely to continue to be motivated and to learn useful skills in teams. Second, it is possible that some employees who volunteer to become team members with no management encouragement may be behaving opportunistically - they are simply seeking a paid break from their daily production work, provided that they are paid hourly and not by piece rate. This line of reasoning also suggests that the performance-enhancing effects of team membership may be smaller and short-lived for such unsolicited and volunteered team members than for solicited members. Third, it is also possible that management solicitation serves as a credible signal to the solicited workers that management considers them in the viable pool of candidates to become line supervisors (or in the promotion tournament). Having been convinced that they are in the promotion tournament, they will be motivated to work harder to win the tournament. Thus the performance-enhancing effect of team membership will be greater and more long-lasting for solicited members than for unsolicited members. 
Hawthorne effects may be particularly relevant for solicited members. Specifically, it is likely to be solicited team members (rather than volunteers) who consider themselves special or who receive particular attention from management. Thus, the existence of a Hawthorne effect would also point to a greater initial improvement in performance after the start of team membership for solicited members than for other members. However, since the literature also suggests that the Hawthorne effect should wear away over time, this implies that the performance-enhancing effect of team membership for solicited members is expected to be particularly short-lived. Hence, if it is a Hawthorne effect that is driving enhanced performance by solicited team members, the time profile of the performance improvements is predicted to be quite different compared to the pattern that is consistent with the first three hypotheses discussed previously.

The sixth hypothesis concerns the relationship between the performance effects of team membership and the level of education. It is plausible that team members with more education learn lessons from team activities and apply such lessons to their regular work more effectively. Simply put, education and teams may be complementary. The potential importance of such complementarity has been suggested in the literature yet there is very little systematic evidence on it. $^{14}$

Finally we briefly consider the other main set of effects, the indirect or spillover effects. Teams may improve not only team members' performance but also non-team members' performance. One source of these gains flows from teams solving various work problems, thus contributing to the overall efficiency of the workplace and to both members and non-team members working in the same workplace improving their performance. Also, the better

\footnotetext{
${ }^{14}$ For example, Ichniowski, Shaw and Prennushi (1997) find evidence for formal off-the-job training as an important ingredient of the high performance work system. Our study complements their work by testing more directly whether improvement in individual worker performance as a result of team membership is greater for more highly educated workers.
} 
alignment of the goals of team members with firm's objectives may lead to more horizontal or per monitoring by team members so that non-team members are less likely to shirk and thus their performance also improves. While the central focus of this paper is the direct effects of teams, the available data will enable us to provide some limited evidence on indirect effects as well. ${ }^{15}$

\section{Previous Empirical Work}

While there is an enormous amount of previous empirical work by economists in this broad area, most studies examine only our first hypothesis-- the impact of "participation" on business performance. Furthermore, for the most part, the empirical economics literature has not used data that provides direct evidence on the impact of participatory practices such as teams on the behavior of individual workers and then by extension to the impact on organizational and ultimately enterprise performance. Instead, in part because of the difficulties in obtaining adequate economic data for individuals, studies have used data at higher levels of aggregationmainly at the level of the firm, though increasingly at the plant level. In these studies, if links between, for example, enhanced business performance and "participation" have been identified then these have been ascribed to the influence of the existence of a particular participatory practice on individual behavior. However, such ascription does involve a leap of faith - the available evidence on the posited link between individual behavior and firm performance remains largely indirect.

Similarly, the need to use data at the firm or establishment level has meant that testing of hypotheses that relate to the expected timing of the impact of participation, or to the effect of differences in individual worker characteristics largely have been unable to be undertaken. Also,

${ }^{15}$ As in the case of many Japanese quality circles (Kaizen, JK, ZD), the offline team introduced by our case stresses the importance of not only the actual outcome (concrete solutions to problems) but also the process of problem solving in team (transforming regular front-line workers to motivated, inventive, "smart" workers who are more cognizant of the crucial importance of quality). 
the literature has tended to focus on the impact of participation on outcomes that are comparable across firms, such as value added (rather than production) and much less attention has been devoted to the impact of participation on outcomes such as quality. ${ }^{16}$

There are, however, a handful of studies that do make important steps in beginning to provide direct evidence on hypothesized links between HPWPs such as teams and individual behavior. A number of pioneering studies (e.g. Lazear, 2000, Kleiner and Helper, 2003, Fernie and Metcalf, 1999, Paarsh and Shearer, 1999, and Knez and Simester, 2001), focus on the effects on individual worker performance of the switch from time rates to piece rates or to performance pay. ${ }^{17}$ A related line of work examines the effects on individual worker performance of the shift to team production (e.g. Batt, 1999 and Hamilton, Nickerson and Owan, 2002). ${ }^{18}$

The research of Hamilton, Nickerson and Owan (2002) is probably the closest to our study. They use panel data for a textile plant to empirically examine worker productivity and participation as the plant gradually moved to a team production system. They find among other things that the adoption of on-line teams at the plant improved worker productivity by $14 \%$ on average. Our study differs from theirs in three important ways. ${ }^{19}$ First, we examine the impact of offline team membership as opposed to online team membership. In this sense, both studies are complementary. Second, we use not only a productivity measure but also two additional performance measures, including the product rejection rate, which is an objective measure of quality, and downtime. Finally, our rich data includes measures of worker characteristics and

${ }^{16}$ An important exception is Ichniowski, Shaw and Prennushi (1997) who use plant-level data on productivity and product quality.

${ }^{17}$ More recent contributions include Bandiera, Barankay, and Rasul (2005) and Shi (2007)..

${ }^{18}$ Nagin, et al. (2002) examines the impact on opportunistic behavior of call center employees of exogenously introduced variation in monitoring.

${ }^{19}$ There is, however, an important methodological implication of this difference in the type of teams. Once individuals become online team members, individual performance data may no longer be available and instead may have to be replaced with aggregate team performance data (as in Hamilton, Nickerson and Owan, 2002). By contrast, in our study, the available performance data do not change before and after individuals become offline team members. By continuing to have access to individual 
thus allow us to test additional hypotheses, notably whether the performance effects of team membership are greater for team members with more formal schooling and team members who were sought after by management.

\section{The Case, Data and Descriptive Statistics}

Our case, hereafter PARTS, is a privately owned, non-unionized subsidiary of a multinational firm. At the end of November 2001 PARTS employed 225 employees, including 134 operators who were directly involved with production. PARTS is a single-plant firm (as opposed to a multi-plant firm), and all 134 operators work in the same plant. PARTS has grown rapidly from 30 workers in 1988 and real sales have tripled since 1995 . However the industry is very competitive and profit margins are thin.

PARTS is a light manufacturing firm that makes a range of small components mainly to be used by larger manufacturers. ${ }^{20}$ Typically production items are produced in large runs. While products would not be classified as "hi tech," customers demand high quality - e.g. they specify very low tolerances in crucial components that PARTS manufactures. These parts are produced by different machines that require different though typically not very high levels of skill to operate. While the nature of the technology sets limits to rates of production, the machines permit large discretion in tasks performed by operators so that there is much scope for variation in the quality of the product produced by different operators who use the same machine.

During the study period, hourly workers typically started at $\$ 6$, though normally within a year they were earning $\$ 7.50$ an hour. During the decade preceding our study this firm had

daily performance data we believe we are using those data that are most pertinent for rigorous hypothesis testing of the impact of membership in offline teams.

${ }^{20}$ Our confidentiality agreement with PARTS prohibits us from identifying the specific product they produce. 
never laid off employees although occasionally the firm had dispatched workers on a fixed term basis (6 months) to neighboring firms.

Teams were started at PARTS in June 1999 after the introduction of teams by the parent firm. The CEO appears to have taken the introduction of teams seriously, including hiring a fulltime consultant with long experience in the introduction of teams at other firms. Each team consists of on average of eight team members including one engineer. All team members except for the assigned engineer are operators from different workplaces. As in the case of many offline teams introduced by U.S. firms, teams are modeled after Japanese small group activities (QC circles). ${ }^{21}$ Each team works on a series of specific themes and meets on average for 30 to 45 minutes a week. As such they are offline teams as opposed to online teams (the wholesale transformation of regular workplaces into self-directed team production units, such as cell production or modular production). As in the case of many Japanese QC circles, outcome (concrete solution to a specific theme or problem) is just as important as process, through which team members learn valuable lessons, become more motivated, more inventive and "smarter" workers with clearer awareness of the importance of quality control. The only notable departure from traditional Japanese QC circles is that team meetings at PARTS take place during regular hours as opposed to after hours. ${ }^{22}$

Importantly for our analysis the way teams were introduced means that not all workers were team members. Participation in teams is in principle voluntary although management sometimes solicits certain workers to become team members (we will discuss this in more detail later as well). There is no compensation for team participation, although team participation is evaluated as an important part of the annual performance evaluation process.

${ }^{21} \mathrm{We}$ observed team meetings and could not help noticing the frequent use of typical Japanese QC circle vocabularies, such as Kaizen, Zero Defects, and Just-in-time.

${ }^{22}$ For detailed institutional information on Small Group Activities in Japan, see for instance Cole (1989) and Kato (2003). 
The centrality of teams in the evolving system of human resource management practices at PARTS is perhaps indicated by the relatively limited development of other "high performance workplace practices." Thus while all-employee meetings are held each month (in fact on pay day, the second Thursday of every month), the meetings last only 30 minutes and there are rarely questions and answers and confidential information is not shared. Perhaps more importantly, financial participation by non-managerial employees is quite limited. There is, for example, no plan providing for profit sharing or employee ownership. However, during the last four years the firm has contributed $\$ 500$ each year to each employee's $401 \mathrm{~K}$ plan as a discretionary bonus. Employees seem to expect to receive this bonus unless the firm has a particularly bad year. Neither management nor labor considers it a profit sharing plan.

To help to gain a detailed knowledge of the nature of production and the realities of key dimensions of labor relations at the plant, several types of data were gathered. Special attention was paid to the nature and functioning of offline teams. During a preparatory stage, lengthy interviews with diverse, notably managerial personnel, were conducted. Also a questionnaire was completed that used responses from the principal HR manager. Finally, worker shadowing exercises were conducted over periods of one to three months. These data sources provide much suggestive anecdotal information that, in general, team members viewed teams in a positive light. Thus during worker-shadowing one worker attested: "Recommendations made by teams affect our work at least to some extent and plans are very likely to be carried out". At the same time we heard claims that while teams may initially have had favorable impacts, over time these benefits were believed to have lessened. Also the CEO told us that he was clearly aware of falling enthusiasm among team members. In other words, with the passage of time, in the absence of tangible rewards, the interest of employees in being cooperative and their levels of loyalty appear to have fallen. 
We also observed several examples of projects that offline teams at PARTS had suggested and which have been implemented. For example, the existing labeling system for spare parts was somewhat illogical and quite confusing. A team decided to tackle this problem. All members of the team began with studying production process and various parts used in the process, and eventually developed a new labeling system which reduced the time required for labeling by half and reduced product defect caused by the use of wrong parts. Through such team activities, all team members acquired a deeper understanding of not only the labeling system but also the overall production system and developed a more acute awareness of the devastating consequences of using wrong parts and hence generating faulty products. Furthermore, naturally all members of the team were intimately familiar with the new labeling system and hence their regular daily operations also benefitted from such deep knowledge of the new labeling system.

To provide more systematic information on the potential impact of teams on worker attitudes and behaviors (and thus potentially on firm outcomes), we also undertook an unusual face-to-face survey of workers in March 2001 and received a very high response rate (close to 90 percent). Since findings from that study are detailed elsewhere, here we simply summarize the major findings. ${ }^{23}$ Relative to non-team members, team participants consider themselves to be more empowered, sensed that more information was being shared by management, communicated more often with managers and supervisors within their work groups or teams, and communicated more often with workers outside of their work groups or teams. In addition the survey findings indicate that participants in teams put more effort into their work. The evidence is equally suggestive that attitudes and thus potentially the behavior of team members was being affected in other ways. Thus we find some evidence for participants displaying stronger organizational commitment and more trust towards management. In addition we note that team

\footnotetext{
${ }^{23}$ See Jones, Kato and Weinberg (2003).
} 
members are, more satisfied with their jobs, more positive about the use and contributions of their knowledge and skills and that there is no difference between team members and other workers concerning views on job stress.

In sum, findings based on interviews with HR officials, worker-shadowing, and surveys of individual employees together present a reasonably consistent story suggesting that the introduction of and membership in offline teams has been producing behavioral change in team members. However, there were also some indications that there were some interesting dynamics at work concerning the impact of these developments on individual behaviors. Finally, these data provide reasonably strong evidence of change in many of those areas that several theorists have long stressed, including trust, commitment and discretionary effort.

To provide compelling evidence, however, that teams do lead to actual changes in measurable outcomes such as production, hypotheses must be tested using appropriate and detailed economic data. In this respect we were fortunate to obtain two sets of data for all 134 operators who were employed by PARTS as of November 30, 2001. First, for each of these 134 operators, we collected daily performance data during the 35-month period, from January 1, 1999 through November 30, 2001. These daily performance data were then matched with personnel records containing information on worker characteristics, including date of hire and education. These records also indicate whether individual workers were team members at some point during the period of data collection and, if so, whether they were volunteers or solicited by management. Hence we end up with a very large rich and unusually reliable micro data set. ${ }^{24}$

Table 1 reports descriptive statistics for operators. The average operator is 39 years old with 3.8 years of tenure with PARTS, and his/her wage is quite low ( $\$ 7.64$ an hour). The bulk

${ }^{24} \mathrm{We}$ also have daily performance data for those operators who worked during part of this period yet were no longer employed by PARTS on November 30, 2001. Unfortunately, PARTS did not keep personnel records on these workers and hence we know very little about their worker characteristics (most 
of operators (62\%) are female and 33\% have education beyond high school (yet virtually nobody has a 4-year college degree). ${ }^{25}$ To see if team members differ systematically from non-team members in terms of some key worker characteristics, we also report descriptive statistics according to team status. From Table 1 we see that 54 operators joined teams during the sample period. Reassuringly in most respects the characteristics of team participants and those who were never in teams are quite similar. ${ }^{26}$ The only exception is gender, with team members much more apt to be female. In short, except for gender, there is no evidence to suggest systematic bias in team participation in terms of observable worker characteristics.

Data were collected for three key measures of individual performance. The first measure is EFFICIENCY which expresses individual production as a percentage of a "norm" that is set for each machine (and which remained unchanged during the sample period.) Since most machines have an automatic counter that records each workers' output each day, these data are extraordinarily reliable. The set of EFFICIENCY numbers for a worker during a year is used in the annual evaluation of each worker's performance by his supervisor.

The second performance measure is the REJECTION RATE. This is a measure of quality and records the amount of defective production produced by an individual as a percentage of that individual's production. To compile these data each production worker's output is tested randomly (on average every other day.) Thus the REJECTION RATE is recorded for each worker for each audit day. Again these data are most unusual and are apt to be characterized by very tiny measurement errors. These sets of rejection rate data, as gathered during a year for each

importantly their dates of hire). However, when possible, we will use the daily performance data for those "job leavers" to check the robustness of our results.

${ }^{25}$ Unfortunately data on education are missing for 31 workers.

${ }^{26}$ Note that in many respects the workers in the firm are quite homogeneous. In addition there are no sharp differences in race and nationality. In such circumstances we expect that "social connectedness" is apt to be high (Glaeser et al., 1999). Consequently we might expect that the potential for the introduction of teams fostering trust is especially high in such circumstances. 
individual, are also used as part of the annual evaluation process of each worker's performance by her supervisor.

The third performance measure is individual DOWNTIME. This measures downtime hours for each individual for each day and includes all time not spent in production. This includes time spent setting up a station, time spent waiting for parts, machine repair, greasing, various meetings (including team meetings), training, cleaning up time, and time spent on any other breaks (including for illness and snacks.) Again these data are collected for each individual for each day.

Data for the three measures are shown in Table 2. Average EFFICIENCY, REJECTION RATE, and DOWNTIME for all workers are, respectively $83.487 \%, 0.561 \%$, and 0.890 hours per day. The rest of Table 2 presents average EFFICIENCY, REJECTION RATE, and DOWNTIME before and after individual workers become team members. ${ }^{27}$ The data reveal that for all team members average EFFICIENCY is higher after joining a team (84.955 vs. 78.643\%) representing an average 6.312 percentage-point improvement in productivity. Turning to the data on the REJECTION RATE we see that the average REJECTION RATE is considerably lower for team members $(0.399$ vs. $0.814 \%)$. This represents an average 0.415 percentage-point improvement in this measure of quality after workers became team members. Finally, when we look at DOWNTIME we see that average DOWNTIME is higher after workers joined teams ( 0.969 vs. 0.665$)$ or, on average, 0.304 hours (18 minutes a day) higher. All differences in average EFFICIENCY, REJECTION RATE, and DOWNTIME before and after team membership are statistically significant at the 1 percent level.

For team members, we undertake similar analyses depending on whether or not team membership resulted from management solicitation and whether team members have education

${ }^{27}$ During the 35-month period, no team member quit participating in his/her team to become a non-team member. 
beyond high school or not. ${ }^{28}$ These findings are reported in Table 2 . For all sub-groups of team members we find similar directional changes in all three performance measures after joining teams. All differences in average EFFICIENCY, REJECTION RATE, and DOWNTIME before and after the onset of team membership are statistically significant at the 1 percent level except for EFFICIENCY of team members without education beyond high school. Solicited team members show a substantially greater improvement in the REJECTION RATE than do unsolicited team members, whereas the size of EFFICIENCY gains seem to be somewhat smaller for solicited members than for unsolicited members. We also observe that unsolicited members increase their DOWNTIME after team membership begins considerably more than solicited members; this suggests possible opportunistic behavior by unsolicited members. With regard to education, the size of improvements in EFFICIENCY and REJECTION RATE appear to be greater for more educated workers than for less educated workers, whereas the size of the increase in DOWNTIME increase seems to be comparable, suggesting a possible complementarity between education and teams.

Finally, to see if team members perform differently to begin with than non-members, we add descriptive statistics for non-team members to Table 2. These data show that it is nonmembers that have higher EFFICIENCY and lower REJECTION RATE (compared to team members, at least before they joined teams). In other words, there appears to be no "cherry picking." In addition, team members (at least before they joined teams) had lower DOWNTIME than non-members - there is no evidence that team members were prone to have more downtime to begin with than non-members.

${ }^{28}$ The data on whether or not each team member was solicited by management are provided by the full-time consultant who has been in charge of all team activities since the introduction of offline teams. 


\section{Empirical Strategy and Findings on Worker Performance}

To investigate with more precision the suggestive findings from the previous section, we undertake a number of exercises. Our baseline model is a simple fixed effects model:

$$
\begin{aligned}
\mathrm{P}_{\mathrm{it}}=\alpha \text { MEMBER }_{\mathrm{it}}+\beta(\text { DAYS IN TEAM })_{\mathrm{it}}+(\text { individual specific fixed effects }) \\
+(\text { monthly time dummy variables })+\mathrm{u}_{\mathrm{it}}
\end{aligned}
$$

where $\mathrm{P}_{\mathrm{it}}$ is performance of worker $\mathrm{i}$ in day $\mathrm{t}$; MEMBER $\mathrm{it}_{\mathrm{it}}$ is a dummy variable which takes the value of 1 if worker $i$ is a team member in day $t$, and the value of zero otherwise. This model enables us to investigate the first four hypotheses, including our two core hypotheses concerning the impact of teams on productivity and quality. That is, for the three measures of $\mathrm{P}_{\mathrm{it}}$ (namely EFFICIENCY, REJECTION RATE and DOWNTIME), the estimated coefficients on $\mathrm{MEMBER}_{\mathrm{it}}$ are used to test whether or not team membership affects individual performance. In addition, we include (DAYS IN TEAM) it (the number of days in a team in 100 days) in order to test the fourth hypothesis concerning whether or not the impact of organizational changes introduced alone can deliver sustained benefits in firm performance. That is, in the absence of complementary initiatives the performance effects of team may be expected to change (deteriorate) as that program continues without the benefit of other reforms.

We include individual specific fixed effects to capture the time-invariant unobserved heterogeneity of our workers. In particular, individual specific fixed effects will attempt to control for differences among workers in their innate abilities. If workers with high innate abilities are more likely to join teams, the coefficients on MEMBER might indicate the effects of superior innate abilities of workers in general as well as the actual effects of team membership. Individual specific fixed effects will help separate the two effects.

We also include 34 monthly time dummy variables to capture time-specific shocks to PARTS that are common to all production workers. (There are actually 35 monthly time dummy 
variables from January 1999 through November 2001. We use the January 1999 time dummy variable as a reference month.)

To see if the estimated coefficients on MEMBER it $_{\text {and }}$ (DAYS IN TEAM) it $_{\text {change when }}$ the tenure of the worker is controlled for, we also considered an additional specification. In this estimate, the tenure of the worker (the number of days for which he/she has been with PARTS) and its square are added to Eq. (1). ${ }^{29}$

The coefficient on MEMBER $_{\text {it }}$ can be interpreted as gauging how much each individual worker's performance changes as a result of his/her participation in an offline team. The coefficient on (DAYS IN TEAM) it can be interpreted as indicating to what extent the initial impact of team participation changes as his/her team experience increases.

Note that the coefficient on $\mathrm{MEMBER}_{\mathrm{it}}$ is not capturing the indirect spillover effect of team participation on performance of non-team members and hence the overall factory-wide performance. Estimation of such overall team effects is usually subject to a selection issue. That is, all workers realize that the introduction of offline teams signifies that the firm's HR strategy is shifting more towards a high performance/high involvement HR system whereby high-ability workers are more highly valued and low-ability workers find work more challenging, demanding and difficult. As a result, low-ability workers find the shift an unwelcoming event and are more prone to quit than high-ability workers. If this is the case, the overall performance of the firm will improve even if there is no motivational effect of the introduction of teams on team members since the introduction of teams weeds out low-ability workers.

However, the focus of this study is not overall firm-wide team effects, but rather the changes in performance of the same worker before and after joining a team. At the same

${ }^{29}$ To avoid multicollinearity between time dummy variables and TENURE, we also tried to restrict the sum of all monthly time effects to be zero. The estimated coefficients on MEMBER and DAYS IN TEAM prove to be insensitive to such a restriction. 
time, we recognize that if poorly performing team members are more likely to quit than are other team members, then the estimated coefficients on MEMBER $_{\text {it }}$ would be subject to a similar selection issue (or we would be overestimating the motivational effect on team members of team participation). However, our data reveal that no team member quit during the 35-month study period. This total absence of attrition from teams was confirmed by managers of PARTS. Hence, we expect the selection issue to be much less relevant in this study. To confirm this conjecture, we will examine whether the estimated coefficient on MEMBER ${ }_{i t}$ will change significantly when including those operators who left PARTS during the 35-month period.

Table 3A summarizes the fixed effect estimates of Eq. (1). ${ }^{30}$ We begin first by discussing findings for the first hypothesis on the impact of team membership on EFFICIENCY (we drop subscripts for exposition from now on.) A clear and consistent finding is that there is a positive and significant effect on EFFICIENCY of MEMBER thus indicating that team membership leads to improvements in productivity. This effect is apparent in both specifications (with and without controlling for the possible tenure effect) and is estimated at plausible levels (about a 3\% gain in EFFICIENCY).

The effects of team membership on the REJECTION RATE are also reported in the same table. Essentially the results reported parallel those for EFFICIENCY. The key result is a clear and consistent finding of a negative and significant effect on the REJECTION RATE of MEMBER, thus indicating that team membership results in an improvement in quality. While the average improvement in the REJECTION RATE is a modest 0.15 percentage point, this

\footnotetext{
${ }^{30}$ One might wish to adjust the standard errors to account for possible clustering due to the possibility that the error terms of operators on the same team are correlated. Unfortunately, we are unable to calculate cluster-adjusted standard errors, for we do not know who belongs to which team.
} 
represents a $27 \%$ improvement in the average REJECTION RATE and thus constitutes strong support for our second core hypothesis. ${ }^{31}$

To provide a test of the third hypothesis we begin by examining the impact of teams on DOWNTIME. In both specifications (with and without controlling for tenure effects), membership in a team is accompanied by a positive and significant effect on DOWNTIME -team membership results in more downtime. Specifically, for the average team member there is a 0.25 hour (15 minutes) increase in daily DOWNTIME to begin with. This is consistent with hypotheses that predict the existence of significant initial costs to investing in participatory institutions such as teams. The major cost in this case is the forgone operation hours of team members since team meetings are held during regular working hours. But in addition, we observe that the estimated coefficients on DAYS IN TEAM are negative and statistically significant, falling by about $6 \%$ in 100 days after becoming a team member. This indicates that the cost of teams will diminish as team members increase their experience with teams and learn how to run their team meetings effectively. Thus again we have strong support for our hypothesis.

In examining the evidence as it bears on the fourth hypothesis, we note that in the EFFICIENT estimates, the negative coefficient on DAYS IN TEAM indicates that the positive team effect will diminish as time goes by. Specifically, the positive team effect on EFFICIENCY will fall by about $10 \%$ per 100 days in team. Furthermore, we observe a similar effect in the REJECTION RATE equation -- the team effect will weaken as DAYS IN TEAM rises, specifically diminishing by about $16 \%$ in 100 days after the average worker becomes a team member. As such these findings provide evidence that is consistent with the hypothesis that, in the absence of complementary initiatives, the beneficial effects of measures introduced

${ }^{31}$ We also used Tobit models to account for zeros in REJECTION RATE and found no discernable changes in our results. 
alone (such as teams) can be expected to be short-lived as the motivational effects of employee involvement alone are undermined over time.

As we argued earlier, the performance-enhancing effect of team membership may be due to learning, i.e., team members learn through team activities new skill/knowledge that is useful for their regular work. Such a human capital interpretation of the performance-enhancing effect of team membership is also consistent with our results. Initially team members take full advantage of their newly acquired human capital and improve their performance. However, in the absence of financial participation which links worker pay to performance, workers will stop taking full advantage of their new skill/knowledge acquired through team activities and hence performance gains are eroded over time.

Note that our evidence is also consistent with the Hawthorne effect. However, later we will provide evidence that the Hawthorne effect interpretation may not be particularly relevant to our case.

To check whether our estimates are sensitive to the inclusion of those workers who left PARTS during the period, we re-run the regressions reported in Table 3A but also include data for operators who left during the period. There results are reported in Table 3B. As expected, it is clear that our key findings are unaffected by the inclusion of these data for "job leavers". The size and direction of all coefficients are essentially unaltered by the use of this larger data set. ${ }^{32}$

To study team effects separately for solicited and unsolicited team members, we modify Eq. (1) as follows:

$$
\begin{aligned}
& \mathrm{P}_{\mathrm{it}}=\alpha_{\mathrm{S}}(\text { SOLICITED MEMBER })_{\mathrm{it}} \\
& +\beta_{\mathrm{S}}(\text { SOLICITED MEMBER })_{\mathrm{it}} *(\text { DAYS IN TEAM })_{\mathrm{it}} \\
& +\alpha_{\mathrm{U}}(\mathrm{UNSOLICITED} \mathrm{MEMBER})_{\mathrm{it}}
\end{aligned}
$$

${ }^{32}$ Since no personnel records are available for those who left during the sample period, we are unable to consider the tenure of the worker as an additional control. 
$+\beta_{\mathrm{U}}(\mathrm{UNSOLICITED} \text { MEMBER })_{\mathrm{it}}{ }^{*}(\mathrm{DAYS} \text { IN TEAM })_{\mathrm{it}}$

$+($ individual specific fixed effects $)+($ monthly time dummy variables $)+u_{i t}$

where $(\text { SOLICITED MEMBER })_{\mathrm{it}}$ is a dummy variable which takes the value of 1 if worker $\mathrm{i}$ is a solicited team member in day $t$, and the value of zero otherwise; and (UNSOLICITED

MEMBER $)_{\text {it }}$ is a dummy variable which takes the value of 1 if worker $i$ is an unsolicited team member in day $t$, and the value of zero otherwise.

Likewise, to study the team effects separately for team members with and without education beyond high school, we modify Eq. (1) as follows:

$$
\begin{aligned}
& P_{i t}=\alpha_{M}(\text { MORE EDUCATED MEMBER })_{i t} \\
& +\beta_{M}(\text { MORE EDUCATED MEMBER })_{i t}{ }^{*}(\text { DAYS IN TEAM })_{i t} \\
& +\alpha_{\mathrm{L}}(\text { LESS EDUCATED MEMBER })_{i t} \\
& +\beta_{\mathrm{L}}(\text { LESS EDUCATED MEMBER })_{i t} *(\text { DAYS IN TEAM })_{i t} \\
& +(\text { individual specific fixed effects })+(\text { monthly time dummy variables })+u_{i t}
\end{aligned}
$$

where (MORE EDUCATED MEMBER) $)_{\text {it }}$ is a dummy variable which takes the value of 1 if worker $\mathrm{i}$ has education beyond high school and is a team member in day $\mathrm{t}$, and the value of zero

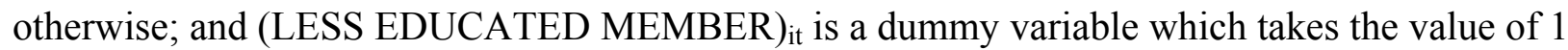
if worker i does not have education beyond high school and is a team member in day $t$, and the value of zero otherwise.

Table 4A reports the fixed effect estimates of Eq. (2). The most striking and statistically significant difference in the team effects between solicited and unsolicited team members lies in the time profile of the team effects. The performance gains from team membership will fall as unsolicited members spend more time in teams whereas they will not fall as solicited members spend more time in teams (in fact, the positive EFFICIENCY gains from team membership will rise significantly as time passes for solicited members). Furthermore, concerning DOWNTIME, and again as expected, the increase in DOWNTIME as a result of team membership is 
considerably greater for unsolicited members than for solicited members. In addition, such increases in DOWNTIME will fall more slowly for unsolicited members as time goes by. All these differences between solicited and unsolicited members are found to be statistically significant at least at the 5 percent level. Finally, the team effects on EFFICIENCY and the REJECTION RATE are found to be greater for solicited team members than for unsolicited members although we are unable to reject the null hypothesis of $\alpha_{S}=\alpha_{U}$ at the 10 percent level. In sum, the evidence is consistent with our conjecture that skilful personnel managers will have a better sense of those individuals who will likely be better fits as team members and also which individuals are more likely to continue to get motivated and to learn useful skills in teams. Our findings also support the hypotheses that some of those employees who volunteer to become team members with no management encouragement may be behaving opportunistically — they are simply seeking a paid break from their daily production work. Furthermore our findings support the signaling hypothesis that management solicitation serves as a credible signal to solicited workers that management considers them in the viable pool of candidates to become line supervisors. Finally, we find no evidence that the performance-enhancing effect of team membership erodes over time for solicited members whereas we do find such evidence for nonsolicited members. As such, these findings are not consistent with the Hawthorne effect which predicts that the dissipation of the performance-enhancing effect of teams over time will be particularly relevant to solicited members.

To further shed light on the observed differences in the team effects between solicited and unsolicited team members, we run a "pre-program" regression. That is,

$$
\begin{gathered}
\mathrm{P}_{\mathrm{it}}=\alpha+\beta_{\mathrm{S}}(\text { SOLICITED MEMBER })_{\mathrm{i}}+\beta_{\mathrm{U}}(\text { UNSOLICITED MEMBER })_{\mathrm{i}} \\
+\gamma \mathrm{X}_{\mathrm{it}}+(\text { monthly time dummy variables })+\mathrm{u}_{\mathrm{it}}
\end{gathered}
$$


where $\mathrm{t}$ is from January 1, 1999 to May 31, 1999 (i.e. the period prior to the introduction of offline teams); SOLICITED MEMBER $\mathrm{M}_{\mathrm{i}}=1$ if worker i eventually becomes a solicited member, 0 otherwise; UNSOLICITED MEMBER U $_{\mathrm{i}}=1$ if worker $\mathrm{i}$ eventually becomes an unsolicited member, 0 otherwise; and $\mathrm{X}_{\mathrm{it}}$ is a vector of personal characteristics of worker $\mathrm{i}$ in day $\mathrm{t}$ that may affect his/her performance and our data enable us to control for his/her education level, gender, tenure, and its square. For example, when measuring $\mathrm{P}_{\text {it }}$ by efficiency, the estimated coefficients on (SOLICITED MEMBER) $)_{i}$ and (UNSOLICITED MEMBER) indicate whether solicited members (unsolicited members) were initially (prior to the introduction of teams) more or less productive than those who never become team members, after controlling for personal characteristics and time effects. If statistically significant differences in the estimated coefficients between solicited and unsolicited members emerge, potentially this will provide additional insights into the process by which managers solicit team-members.

Table 4B summarizes the OLS estimates of Eq. (4). After controlling for tenure, education, gender and time effects, prior to the introduction of teams, solicited team members were found to be 9 percentage-points less efficient than non-team members, while unsolicited team members were 13 percentage-points less efficient than non-team members. The efficiency differential between solicited and unsolicited team members is found to be statistically significant at the 10 percent level. The quality measure (rejection rate) results suggest that solicited team members were initially producing substantially more defects than non-team members, whereas unsolicited team members were similar to non-team members in terms of their rejection rates. The quality differential between solicited and unsolicited team members is statistically significant at the 1 percent level. Finally, for solicited members, downtime was initially more than 20 minutes less per day than for non-team members, whereas downtime for unsolicited members was initially 15 minutes less than for non-team members. The pre-program 
differential in downtime between solicited and unsolicited members is found to be statistically significant at the 10 percent level.

In short, our pre-program regression results suggest that even after controlling for observable individual characteristics of workers and time effects, management solicitation appears to have been focused on underperforming operators, in particular those with more room for quality improvement. In addition, the targeted operators were also initially spending more time on production and hence had more room for downtime to increase, such as through team meetings.

Conceivably, initially solicited operators might have been operating particularly difficult machines which resulted in low efficiency and high rejection rates and, after participating in teams, they might have been assigned to easier machines. If this were in fact the case, then the observed efficiency and quality gains from team membership would simply have resulted from such systematic machine reassignments. However, based on extensive and separate interviews with the $\mathrm{CEO}$, the general production manager and a key contact who is in charge of teams, we are persuaded that the introduction of team membership was not accompanied by any systematic task reassignments. ${ }^{33}$

The fixed effect estimates of Eq. (3) are reported in Table 5. The most significant difference between more and less educated team members is found in the team effects on the REJECTION RATE. The estimated coefficient on MEMBER is statistically significant only for more educated team members, implying that the quality gains from team membership are felt only by team members with more education. The estimated coefficient on (LESS EDUCATED MEMBER)*(DAYS IN TEAM) is, however, negative and statistically significant. This suggests that, for less educated team members, while there is no immediate team effect on the

${ }^{33}$ In addition, it is difficult to reconcile the machine reassignment interpretation of the team effects with the dissipation of the effects over time. 
REJECTION RATE, with the passage of time they begin to learn to convert their team experiences into their daily performance in quality assurance. For DOWNTIME, as educated team members engage in learning by doing, the cost of team membership (increased downtime) will diminish. No such significant learning effects are found for less educated workers. For EFFICIENCY, as expected, the team effects appear to be greater and more long-lasting for more educated team members than for less educated team members, although these differences are found to be statistically insignificant at the 10 percent level. Overall, our findings are generally consistent with the sixth hypotheses that there is a complementarity between education and teams.

Finally we briefly consider evidence on indirect spillover effects. In Figure 1 we plot the estimated time effects of "Efficiency" from Eq. (1) along with the number of offline team members. Similarly, Figure 2 shows the estimated time effects of "Rejection Rate" from Eq. (2) along with the number of offline teams. Both Figures show productivity and quality improving over time, though quality improvements appear more promptly. ${ }^{34}$ These patterns coincide with the diffusion of offline teams among operators at PARTS and suggest the presence of indirect spillover effects as captured by estimated time effects. However, since the estimated time effects also include the effects of other external shocks common to all operators at PARTS, such as demand shocks and trends, unfortunately the precise magnitude of the indirect spillover effects cannot be identified.

\footnotetext{
${ }^{34}$ Interviews with the CEO, the production manager, and the manager in charge of teams all confirm that there were no major technological changes (such as the introduction of new machines) at PARTS during the study period.
} 


\section{Conclusions and Implications}

We use extraordinary data to provide some of the most reliable evidence to date on diverse hypotheses concerning the economic impact of offline teams, which are an increasingly important and common form of employee participation in economies around the world. Our first core hypothesis concerns the direct impact of offline teams and employee involvement on individual performance. Based on daily data for various measures of performance including rejection (quality) and production rates for all operators in a single plant during a 35 month period, we find that membership in offline teams results in enhanced performance. While the size of these initial effects depends on the particular specification, gains in efficiency average about $3 \%$, which is a quite believable number given the relatively limited scope that the production process provides for discretionary effort to affect output rates. In our reading of the literature, we find no econometric estimates on the productivity effect of offline teams to which our estimates can be compared. However, Hamilton, Nickerson and Owan (2002) report a 14percent gain in productivity from the adoption of online teams which is considerably larger than our estimated productivity gain. We believe that one of the main reasons for the relatively small productivity gain estimates in our study is that we are capturing only the direct impact on motivation, goal alignment and human capital formation (and thus productivity) for team members of the adoption of offline teams. Our estimated productivity gain does not include possible indirect spillover effects, such as teams solving various productivity problems (and thus enhancing the overall efficiency of the workplace), and team members engaging in peer monitoring and knowledge sharing with non-team members (and hence enhancing non-members' productivity). Consequently our findings may be viewed as lower bound estimates of the effects of teams. The gross gains from teams (and which include indirect spillover effects) may well be greater than what we have captured by our estimates of the direct gains. 
We also provide what may be the first rigorous estimates of the impact of any form of employee involvement, including teams, on product quality. According to our estimates, we find strong support for our second hypothesis-- team membership leads to rejection rates improving by about $27 \%$. These findings on output and quality are consistent with hypotheses that predict that the introduction of (and membership in) teams will produce more trust by employees in management, improved goal alignment between managers and employees and thus enhanced discretionary effort and improved attention to quality. While our evidence may be viewed as complementary to other studies, we again underscore the most unusual nature of our data. Thus, following the adoption of a high performance work system that includes teams among other innovative work practices, Ichniowski, Shaw and Prennushi (1997) also find a statistically significant positive impact on a physical measure of product quality of steel finishing lines. But whereas we use individual worker data, Ichniowski, Shaw and Prennushi (1997) use plant-level data. Also Batt (1999) finds a statistically significant positive effect of online teams for call center workers, though a self-reported rather than an objective measure of quality is used.

We also find clear evidence that the improvements in enterprise outcomes are not sustained at their initial levels. ${ }^{35}$ Improvements tend to dissipate over time at a rate of 10 to $16 \%$ per 100 days in team. However this finding is unsurprising to those who stress the need for complementarities in HR initiatives.

The introduction of teams is also initially accompanied by significant costs as rates of downtime increase. However, consistent with those who predict team-learning effects, these costs diminish over time. As such, HPWPs are best viewed as investments.

Moreover, we find differences in performance following team membership for members solicited by mangers compared to those who volunteer as well as differences in pre-program

${ }^{35}$ As such, our evidence is consistent with the QC circle literature that generally reports the transitory nature of the benefits of QC circles (e.g., Lawler III, 1986, Griffin, 1988, Levine, 1995). 
performance. These findings are consistent with various hypotheses including management's ability to observe the relevant worker qualities, tournament incentives and opportunistic behavior by employees, but inconsistent with hypotheses based on Hawthorne effects. Finally, we find evidence of a complementarity between teams and formal education.

One implication of our finding concerns the payoffs to possible managerial choices that are available to firms today. Some economic theorists argue that firms that operate in today's competitive labor and product markets, have very little discretion in setting wage, employment and human resource management practices. Consequently, these practices are predicted to be broadly similar across firms in similar situations. However, the evidence presented in this paper provides evidence that firms can introduce changes (such as teams) and that, as in the case of PARTS, when a serious attempt is made to introduce an innovative HR policy such as teams, non-negligible benefits to firms are often delivered. Our empirical findings provide much more solid support than was perhaps previously available for those who hypothesize that participatory practices can enhance business performance, even in settings where employee tasks are fairly simple and employees are relatively low-skilled and the firm uses relatively simple technologies to produce components and employs rural low-wage workers with limited education. Finally, our findings indicate that the payoffs to such single innovations may not persist and that the design of HR polices in firms needs constant attention. To provide for enduring gains in firm performance, most likely will require the introduction of complementary initiatives. 


\section{References}

Addison, John T. and Belfield, Clive R. "The Impact of Financial Participation and Employee Involvement on Financial Performance: A Re-Estimation Using the 1998 WERS." Scottish Journal of Political Economy, 2000, 47(5), pp. 571-83.

Alchian, Armen A. and Demsetz, Harold. "Production, Information Costs, and Economic Organization." American Economic Review, 1972, 62(5), pp. 777-95.

Appelbaum, Eileen and Batt, Rosemary. The New American Workplace: Transforming Work Systems in the United States. Ithaca: ILR Press, 1994.

Appelbaum, Eileen ; Thomas Bailey; Peter Berg and Kalleberg, Arne L. Manufacturing Advantage: Why High-Performance Work Systems Pay Off. Ithaca and London: Cornell University Press, ILR Press, 2000.

Baker, George; Gibbs, Michael and Holmstrom, Bengt. "The Internal Economics of the Firm: Evidence from Personnel Data." Quarterly Journal of Economics, 1994a, 109(4), pp. 881-919.

. "The Wage Policy of a Firm." Quarterly Journal of Economics, 1994b, 109(4), pp. 921-55.

Bandiera, Oriana; Barankay, Iwan and Rasul, Imran. "Social Preferences and the Response to Incentives: Evidence from Personnel Data." Quarterly Journal of Economics, 2005, 120(3), pp. 917-62.

Bartel, Ann P. "Human Resource Management and Organizational Performance: Evidence from Retail Banking." Industrial and Labor Relations Review, 2004, 57(2), pp. 181-203.

Bartel, Ann P.; Ichniowski, Casey and Shaw, Kathryn. "Using "Insider Econometrics' to Study Productivity." American Economic Review, 2004, 94(2), pp. 217-27.

Batt, Rosemary. "Work Organization, Technology, and Performance in Customer Service and Sales." Industrial and Labor Relations Review, 1999, 52(4), pp. 539-64.

Ben-Ner, Avner and Jones, Derek C. "Employee Participation, Ownership, and Productivity: A Theoretical Framework." Industrial Relations, 1995, 34(4), pp. 532-54.

Ben-Ner, Avner and Putterman, Louis. "Trust in the New Economy," D. C. Jones, Handbook of the New Economy. New York: Elsevier Science, 2003, 1069-93.

Black, Sandra E. and Lynch, Lisa M. "How to Compete: The Impact of Workplace Practices and Information Technology on Productivity." Review of Economics and Statistics, 2001, 83(3), pp. 434-45.

. "What's Driving the New Economy? The Benefits of Workplace Innovation." Economic Journal, 2004, 114(493), pp. F97-116.

Blair, Margaret M. and Kochan, Thomas A., eds. The New Relationship: Human Capital in the American Corporation. Washington, D.C.: Brookings Institution Press, 2000.

Blinder, Alan S., ed. Paying for Productivity: A Look at the Evidence. Washington, D.C.: Brookings Institution, 1990.

Boning, Brent; Ichniowski, Casey and Shaw, Kathryn. "Opportunity Counts: Teams and the Effectiveness of Production Incentives." Journal of Labor Economics (forthcoming), 2005.

Cappelli, Peter and Neumark, David. "Do "High-Performance" Work Practices Improve Establishment-Level Outcomes?" Industrial and Labor Relations Review, 2001, 54(4), pp. 737-75.

Caroli, Eve and Van Reenen, John. "Skill-Biased Organizational Change? Evidence from a Panel of British and French Establishments." Quarterly Journal of Economics, 2001, 116(4), pp. 1449-92.

Cole, Robert E. Strategies for Learning: Small-Group Activities in American, Japanese, and Swedish Industry. Berkeley and London: University of California Press, 1989. 
Craig, Ben and Pencavel, John. "Participation and Productivity: A Comparison of Worker Cooperatives and Conventional Firms in the Plywood Industry." Brookings Papers on Economic Activity, 1995, 0(0), pp. 121-60.

DeVaro, Jed. "The Effect of Self-Managed and Closely-Managed Teams on Labor Productivity and Product Quality: An Empirical Analysis of a Cross Section of Establishments," Mimeo, Cornell University, 2004.

Dunlop, John T. and Weil, David. "Diffusion and Performance of Modular Production in the U.S. Apparel Industry." Industrial Relations, 1996, 35(3), pp. 334-55.

Eriksson, Tor. "The Effects of New Work Practices - Evidence from Employer-Employee Data.," T. Kato and J. Pliskin, Determinants of the Incidence and the Effects of Participatory Organizations: Advances in the Economic Analysis of Participatory and Labor-Managed Firms. Amsterdam: Elsevier/JAI, 2003, 3-30.

Fernie, Sue and Metcalf, David. "It's Not What You Pay It's the Way That You Pay It and That's What Gets Results: Jockeys' Pay and Performance." Labour, 1999, 13(2), pp. 385411.

Freeman, Richard and Rogers, Joel. What Do Workers Want? Ithaca: Cornell University Press, 1999.

Freeman, Richard B.; Kleiner, Morris M. and Ostroff, Cheri. "The Anatomy of Employee Involvement and Its Effects on Firms and Workers," NBER Working Paper No. 8050, 2000.

Gibbons, Robert. "Incentives and Careers in Organizations," Advances in Economics and Econometrics: Theory and Applications: Seventh World Congress. Volume 2. Cambridge; New York and Melbourne: Cambridge University Press, 1997, 1-37.

Gibbons, Robert and Waldman, Michael. "Careers in Organizations: Theory and Evidence," O. Ashenfelter and D. Card, Handbook of Labor Economics. Volume 3b. Amsterdam; New York and Oxford: Elsevier Science, North-Holland, 1999, 2373-437.

Glaeser, E.; Laibson, D.; Scheinkman, J. and Soutter, Christine. "What Is Social Capital? The Determinants of Trust and Trustworthiness," NBER Working Paper No. 7216, 1999.

Griffin, Ricky W. "Consequences of Quality Circles in an Industrial Setting: A Longitudinal Assessment." Academy of Management Journal, 1988, 31(2), pp. 338-58.

Griliches, Zvi. "Productivity, R\&D, and the Data Constraint." American Economic Review, 1994, 84(1), pp. 1-23.

Hamilton, Barton H. ; Nickerson, Jack A. and Owan, Hideo. "Team Incentives and Worker Heterogeneity: An Empirical Analysis of the Impact of Teams on Productivity and Participation." Journal of Political Economy, 2003, 111(3), pp. 465-98.

Helper, Susan. "Complementarity and Cost Reduction: Evidence from the Auto Supply Industry," National Bureau of Economic Research Working Paper: 6033, 1998.

Holmstrom, Bengt and Milgrom, Paul. "The Firm as an Incentive System." American Economic Review, 1994, 84(4), pp. 972-91.

Huselid, Mark A. and Becker, Brian E. "Methodological Issues in Cross-Sectional and Panel Estimates of the Human Resource-Firm..." Industrial Relations, 1996, 35(3), pp. 400-22.

Ichniowski, Casey ; Shaw, Kathryn and Prennushi, Giovanna. "The Effects of Human Resource Management Practices on Productivity: A Study of Steel Finishing Lines." American Economic Review, 1997, 87(3), pp. 291-313.

Ichniowski, Casey; Thomas Kochan; David Levine; Craig Olson and Strauss, George. "What Works at Work: Overview and Assessment." Industrial Relations, 1996, 35(3), pp. 299-333. 
Jones, Derek C.; Kalmi, Panu and Kauhanen, Antti. "Human Resource Management Policies and Productivity: New Evidence from an Econometric Case Study." Oxford Review of Economic Policy, 2006, 22(4), pp. 526-38.

Jones, Derek C. and Kato, Takao. "The Productivity Effects of Employee Stock-Ownership Plans and Bonuses: Evidence from Japanese Panel Data." American Economic Review, 1995, 85(3), pp. 391-414.

Jones, Derek C.; Kato, Takao and Weinberg, Adam. "Changing Employment Practices and the Quality of Jobs in Central New York: Evidence from Case Studies of Medium-Sized Manufacturing Establishments in Central New York," Eileen Appelbaum, Annette Bernhardt and R. Murnane, Low-Wage America: How Employers Are Reshaping Opportunity in the Workplace. New York: Russell Sage Foundation, 2003, 479-526.

Kandel, Eugene and Lazear, Edward P. "Peer Pressure and Partnerships." Journal of Political Economy, 1992, 100(4), pp. 801-17.

Kato, Takao. "The Recent Transformation of Participatory Employment Practices," S. Ogura, T. Tachibanaki and D. Wise, NBER Conference Report Labor Markets and Firm Benefit Policies in Japan and the United States. Chicago: University of Chicago Press, 2003, 3980.

Kato, Takao and Morishima, Motohiro. "The Productivity Effects of Participatory Employment Practices: Evidence from New Japanese Panel Data." Industrial Relations, 2002, 41(4), pp. 487-520.

Kelley, Maryellen R. "Participative Bureaucracy and Productivity in the Machined Products Sector." Industrial Relations, 1996, 35(3), pp. 374-99.

Kleiner, Morris and Helper, Susan. "Changing Incentives for Production Employees: Impacts on Establishment Economic Outcomes and Worker Satisfaction," Paper presented at the 55th IRRA meeting, Washington, D.C., 2003.

Kochan, Thomas and Osterman, Paul. Mutual Gains Enterprise: Forging a Winning Partnership among Labor, Management, and Government (Hardcover). Harvard Business School Press, 1994.

Lawler, Edward E. III. High-Involvement Management: Participative Strategies for Improving Organizational Performance. San Francisco: Jossey-Bass, 1986.

Lazear, Edward P. "Performance Pay and Productivity." American Economic Review, 2000, 90(5), pp. 1346-61.

Levine, David I. Reinventing the Workplace: How Business and Employees Can Both Win. Washington, D.C.: Brookings Institution, 1995.

Levine, David I. and Tyson, Laura D'Andrea. "Participation, Productivity and the Firm's Environment," A. S. Blinder, ed., Paying for Productivity. Washington, D.C.: Brookings Institution, 1990, pp. 183-236.

MacDuffie, John Paul. "Human Resource Bundles and Manufacturing Performance: Organizational Logic and Flexible Production Systems in the World Auto Industry." Industrial and Labor Relations Review, 1995, 48(2), pp. 197-221.

Medoff, James L. and Abraham, Katharine G. "Experience, Performance, and Earnings." Quarterly Journal of Economics, 1980, 95(4), pp. 703-36.

Milgrom, Paul and Roberts, John. "Complementarities and Fit: Strategy, Structure, and Organizational Change in Manufacturing." Journal of Accounting and Economics, 1995, 19(2-3), pp. 179-208.

Nagin, Daniel S.; Rebitzer, James B.; Sanders, Seth and Taylor, Lowell J. "Monitoring, Motivation, and Management: The Determinants of Opportunistic Behavior in a Field Experiment." American Economic Review, 2002, 92(4), pp. 850-73. 
Osterman, Paul. "How Common Is Workplace Transformation and Who Adopts It?" Industrial and Labor Relations Review, 1994, 47(2), pp. 173-88.

Paarsch, Harry J. and Shearer, Bruce S. "The Response of Worker Effort to Piece Rates: Evidence from the British Columbia Tree-Planting Industry." Journal of Human Resources, 1999, 34(4), pp. 643-67.

Prendergast, Canice. "The Provision of Incentives in Firms." Journal of Economic Literature, 1999, 37(1), pp. 7-63.

Shi, Lan. "Productivity Effect of Piece Rate Contracts: Evidence from Two Small Field Experiments," Mimeo, Department of Economics, University of Washington, Seattle, 2007.

Zwick, Thomas. "Employee Participation and Productivity." Labour Economics, 2004, 11(6), pp. 715-40. 
Table 1 Basic Worker Characteristics of Team Members and Non-team Members as of November 30, 2001

\begin{tabular}{|c|c|c|c|c|c|c|c|c|c|}
\hline & \multicolumn{3}{|c|}{ All operators } & \multicolumn{3}{|c|}{ Members } & \multicolumn{3}{|c|}{ Non-members } \\
\hline & Mean & $\mathrm{SD}$ & $\mathrm{N}$ & \begin{tabular}{|l|} 
Mean \\
\end{tabular} & SD & $\mathrm{N}$ & Mean & $\mathrm{SD}$ & $\mathrm{N}$ \\
\hline Tenure (years) & 3.83 & 3.72 & 134 & 3.52 & 2.84 & 54 & 4.04 & 4.23 & 80 \\
\hline Age & 39.25 & 12.17 & 134 & 37.29 & 9.55 & 54 & 40.56 & 13.56 & 80 \\
\hline hourly wage (dollars) & 7.64 & 1.32 & 134 & 7.67 & 1.27 & 54 & 7.63 & 1.37 & 80 \\
\hline Proportion male (\%) & 38.06 & & 134 & $27.78 * *$ & & 54 & 45.00 & & 80 \\
\hline Proportion with education beyond high school (\%) & 33.33 & & 102 & 40.00 & & 40 & 29.03 & & 62 \\
\hline
\end{tabular}

Source: Personnel data provided by PARTS

Note: ***the difference between members and non-members statistically significant at the $1 \%$ level

**the difference between members and non-members statistically significant at the $5 \%$ level

*the difference between members and non-members statistically significant at the $10 \%$ level 
Table 2 EFFICIENCY, REJECTION RATE, and DOWNTIME

\begin{tabular}{|c|c|c|c|c|c|}
\hline & & & $\begin{array}{l}\text { EFFICIENCY } \\
\text { individual production } \\
\text { as a percentage of norm } \\
\end{array}$ & $\begin{array}{l}\text { REJECTION RATE } \\
\text { individual defective production } \\
\text { as a percentage of total production }\end{array}$ & \begin{tabular}{|l} 
DOWNTIME \\
individual \\
downtime hours \\
\end{tabular} \\
\hline \multirow{3}{*}{\multicolumn{2}{|c|}{ All employees }} & Mean & \begin{tabular}{|l|}
83.487 \\
\end{tabular} & $\begin{array}{ll}0.561 \\
\end{array}$ & 0.890 \\
\hline & & S.D. & 25.756 & 1.775 & 1.067 \\
\hline & & $\mathrm{N}$ & 52944 & 30263 & 52657 \\
\hline \multirow{3}{*}{\multicolumn{2}{|c|}{ All non-team members }} & Mean & 84.196 & 0.502 & 0.918 \\
\hline & & S.D. & 26.904 & 1.713 & 1.065 \\
\hline & & $\mathrm{N}$ & 30734 & 16827 & 30705 \\
\hline \multirow[t]{3}{*}{ All team members } & Before & Mean & 78.643 & 0.814 & 0.665 \\
\hline & After & Mean & 84.955 & 0.399 & 0.969 \\
\hline & \multicolumn{2}{|c|}{ Difference } & $6.312 * * *$ & $-0.415 * * *$ & $0.304 * * *$ \\
\hline \multirow[t]{3}{*}{ More educated members } & Before & Mean & 82.706 & 0.684 & 0.819 \\
\hline & After & Mean & 86.912 & 0.358 & 0.965 \\
\hline & \multicolumn{2}{|c|}{ Difference } & $4.206^{* * *}$ & $-0.326 * * *$ & $0.146^{* * *}$ \\
\hline \multirow[t]{3}{*}{ Less educated members } & Before & Mean & 82.973 & 0.559 & 0.867 \\
\hline & After & Mean & 83.181 & 0.410 & 0.991 \\
\hline & \multicolumn{2}{|c|}{ Difference } & 0.208 & $-0.149 * * *$ & $0.124 * * *$ \\
\hline \multirow[t]{3}{*}{ Solicited members } & Before & Mean & 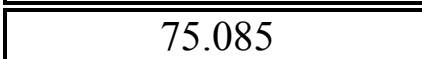 & 1.212 & 0.605 \\
\hline & After & Mean & 79.357 & 0.574 & 0.771 \\
\hline & \multicolumn{2}{|c|}{ Difference } & $4.272 * * *$ & $-0.638 * * *$ & $0.166^{* * *}$ \\
\hline \multirow[t]{3}{*}{ Unsolicited members } & Before & Mean & 80.767 & 0.655 & 0.673 \\
\hline & After & Mean & 87.305 & 0.297 & 1.032 \\
\hline & \multicolumn{2}{|c|}{ Difference } & $6.538 * * *$ & $-0.358 * * *$ & $0.359 * * *$ \\
\hline
\end{tabular}

Source: All data provided by PARTS. Data are for 134 operators at PARTS during the period January 1, 1999 to November 30, 2001. Notes:

1. More educated members=team members with formal education beyond high school.

2. Less educated members=team members without formal education beyond high school.

3. Solicited members=employees who became team members with management soliciation.

4. Unsolicited members=employees who became team members without management soliciation.

***statistically significant at the $1 \%$ level **statistically significant at the $5 \%$ level *statistically significant at the $10 \%$ level 
Table 3A The Effects on EFFICIENCY, REJECTION RATE, DOWNTIME of Team Membership: Fixed Effect Estimates for All Members

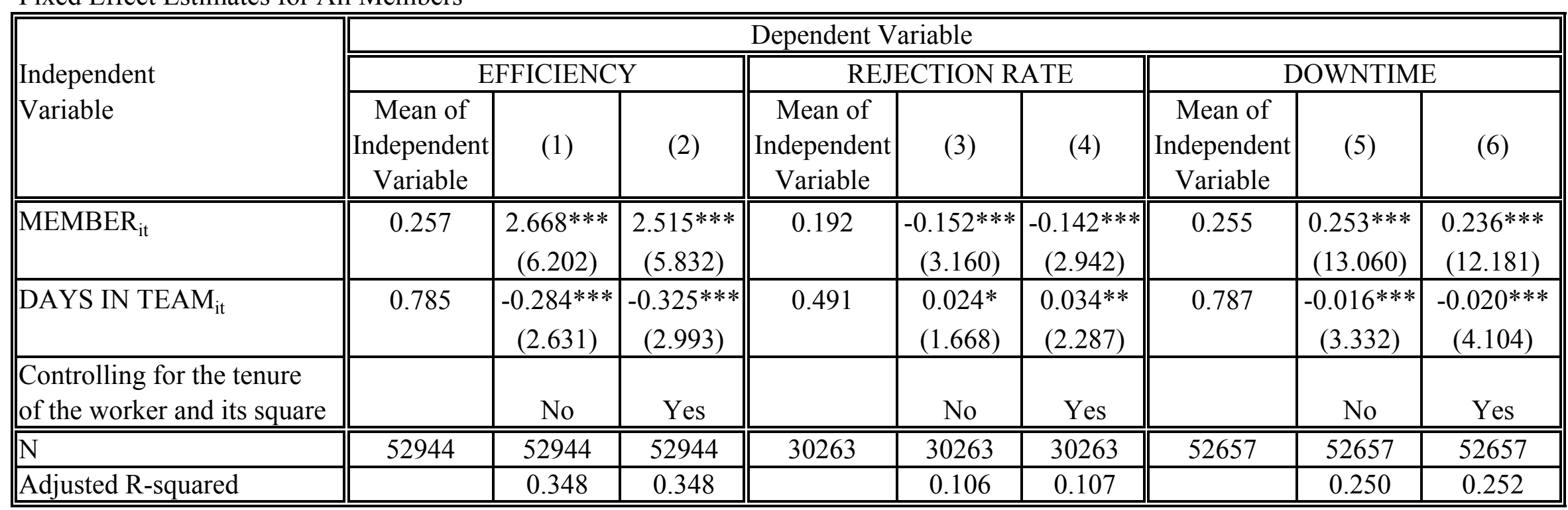

Source: All data provided by PARTS. Data are for 134 operators at PARTS during the period January 1, 1999 to November $30,2001$.

Notes:

1. MEMBER $\mathrm{it}_{\mathrm{it}}$ is 1 if Worker $\mathrm{i}$ is a team member in Time $\mathrm{t}$, and zero otherwise.

2. DAYS IN TEAM ${ }_{i t}=$ the number of days for which Worker $i$ has been a team member at Time $t$.

3. All models include individual fixed effects and monthly time dummy variables. Absolute values of $\mathrm{t}$ statistics are in parentheses.

***statistically significant at the $1 \%$ level **statistically significant at the $5 \%$ level *statistically significant at the $10 \%$ level 
Table 3B The Estiamted Team Effects When Adding Those Who Quit During the Period Fixed Effect Estimates for All Members

\begin{tabular}{|c|c|c|c|c|c|c|}
\hline \multirow{3}{*}{$\begin{array}{l}\text { Independent } \\
\text { Variable }\end{array}$} & \multicolumn{6}{|c|}{ Dependent Variable } \\
\hline & \multicolumn{2}{|l|}{ EFFICIENCY } & \multicolumn{2}{|c|}{ REJECTION RATE } & \multicolumn{2}{|l|}{ DOWNTIME } \\
\hline & \begin{tabular}{|c|} 
Mean of \\
Independent \\
Variable
\end{tabular} & (1) & \begin{tabular}{|c|} 
Mean of \\
Independent \\
Variable \\
\end{tabular} & (3) & \begin{tabular}{|c|} 
Mean of \\
Independent \\
Variable \\
\end{tabular} & $(5)$ \\
\hline MEMBER $_{\text {it }}$ & 0.175 & $\begin{array}{c}2.608 * * * \\
(6.168)\end{array}$ & 0.147 & $\begin{array}{c}-0.160 * * * \\
(3.110)\end{array}$ & 0.173 & $\begin{array}{c}0.252 * * * \\
(13.374)\end{array}$ \\
\hline DAYS IN TEAM ${ }_{\text {it }}$ & 0.534 & \begin{tabular}{|c|}
$-0.364 * * *$ \\
$(3.420)$
\end{tabular} & 0.376 & $\begin{array}{l}0.028 * \\
(1.810)\end{array}$ & 0.534 & $\begin{array}{c}-0.017 * * * \\
(3.563)\end{array}$ \\
\hline $\mathrm{N}$ & 77819 & 77819 & 39488 & 39488 & 77629 & 77629 \\
\hline Adjusted R-squared & & 0.382 & & 0.124 & & 0.252 \\
\hline
\end{tabular}

Source: All data provided by PARTS.

Data are for all operators who worked at least one day at PARTS during the period January 1, 1999 to November 30, 2001. Notes:

1. MEMBER ${ }_{\mathrm{it}}$ is 1 if Worker $\mathrm{i}$ is a team member in Time $\mathrm{t}$, and zero otherwise.

2. DAYS IN TEAM $\mathrm{it}_{\mathrm{it}}=$ the number of days for which Worker $\mathrm{i}$ has been a team member at Time $\mathrm{t}$.

3. All models include individual fixed effects and monthly time dummy variables. Absolute values of $\mathrm{t}$ statistics are in parentheses.

4. No personnel records are available for those who left during the sample period.

***statistically significant at the $1 \%$ level **statistically significant at the $5 \%$ level *statistically significant at the $10 \%$ level 
Table 4A The Effects on EFFICIENCY, REJECTION RATE, DOWNTIME of Team Membership:

Fixed Effect Estimates for Members Sought After by Management and Other Members

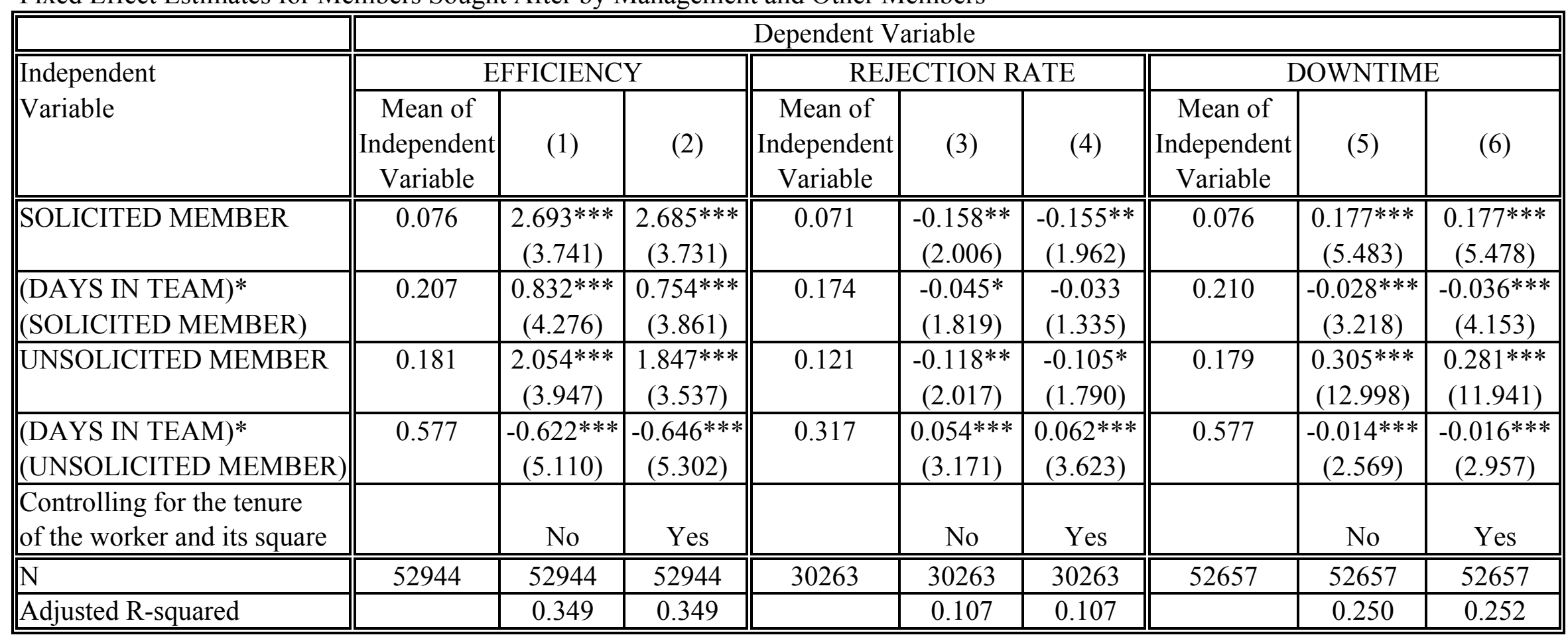

Source: All data provided by PARTS. Data are for 134 operators at PARTS during the period January 1, 1999 to November $30,2001$.

Notes:

1. SOLICITED MEMBER ${ }_{\mathrm{it}}$ is 1 if Worker $\mathrm{i}$ is a solicited team member in Time $\mathrm{t}$, and zero otherwise. (See Table 1 for the definition of solicited members)

2. UNSOLICITED MEMBER $\mathrm{it}_{\mathrm{it}}$ is 1 if Worker $\mathrm{i}$ is a unsolicited team member in Time $\mathrm{t}$, and zero otherwise. (See Table 1 for the definition of solicited members).

3. DAYS IN TEAM $\mathrm{it}_{\mathrm{it}}=$ the number of days for which Worker $\mathrm{i}$ has been a team member at Time $t$.

4. All models include individual fixed effects and monthly time dummy variables. Absolute values of $t$ statistics are in parentheses.

$* * *$ statistically significant at the $1 \%$ level $* *$ statistically significant at the $5 \%$ level *statistically significant at the $10 \%$ level 
Table 4B Pre-Program Regressions

\begin{tabular}{|c|c|c|c|}
\hline Independent Variable & \begin{tabular}{|l} 
EFFICIENCY \\
PRIOR TO JUNE 1999
\end{tabular} & $\begin{array}{l}\text { REJECTION RATE } \\
\text { PRIOR TO JUNE } 1999 \\
\end{array}$ & $\begin{array}{l}\text { DOWNTIME } \\
\text { PRIOR TO JUNE } 1999 \\
\end{array}$ \\
\hline & \begin{tabular}{|c|}
$(1)$ \\
\end{tabular} & $(2)$ & $(3)$ \\
\hline SOLICITED MEMBER & $\begin{array}{c}-9.298 * * * \\
(4.843) \\
\end{array}$ & $\begin{array}{c}0.588 * * * \\
(3.340) \\
\end{array}$ & $\begin{array}{c}-0.370 * * * \\
(5.776) \\
\end{array}$ \\
\hline UNSOLICITED MEMBER & $\begin{array}{c}-12.687^{* * *} \\
(12.146) \\
\end{array}$ & $\begin{array}{c}0.036 \\
(0.475) \\
\end{array}$ & $\begin{array}{c}-0.250 * * * \\
(7.053)\end{array}$ \\
\hline TENURE & $\begin{array}{c}2.748 * * * \\
(17.733) \\
\end{array}$ & $\begin{array}{c}-0.032 * * * \\
(3.079) \\
\end{array}$ & $\begin{array}{c}0.015^{* * *} \\
(2.794) \\
\end{array}$ \\
\hline TENURE $^{2}$ & $\begin{array}{l}-0.064 * * * \\
(17.322)\end{array}$ & $\begin{array}{c}0.001 \\
(2.283)\end{array}$ & $\begin{array}{c}0.000 \\
(1.231)\end{array}$ \\
\hline MORE EDUCATED & $\begin{array}{c}3.271 * * * \\
(3.219) \\
\end{array}$ & $\begin{array}{l}-0.001 \\
(0.011) \\
\end{array}$ & $\begin{array}{c}0.139 * * * \\
(4.057) \\
\end{array}$ \\
\hline MALE & $\begin{array}{l}-8.293 * * * \\
(7.8570) \\
\end{array}$ & $\begin{array}{c}-0.351 * * * \\
(5.3830) \\
\end{array}$ & $\begin{array}{c}-0.049 \\
(1.3850) \\
\end{array}$ \\
\hline $\mathrm{N}$ & 3447 & 2972 & 3522 \\
\hline Adjusted R-squared & 0.098 & 0.028 & 0.104 \\
\hline
\end{tabular}

Source: All data provided by PARTS. Data are for 134 operators at PARTS during the period January 1, 1999 to November 30, 2001.

Notes:

1. SOLICITED MEMBER is 1 if Worker i eventually becomes a solicited team member, and zero otherwise.

2. UNSOLICITED MEMBER is 1 if Worker i eventually becomes an unsolicited team member in Time $t$, and zero otherwise.

3. TENURE is the number of days with PARTS (in 100 days); MORE EDUCATED $=1$ if Worker $i$ has formal education beyond high school, 0 otherwise; and MALE $=1$ if Worker $i$ is male, 0 otherwise.

4. All models include four monthly time dummy variables (February of 1999, March of 1999, April of 1999 and May of 1999; and January of 1999 omitted as a reference month).

Absolute values of $t$ statistics are in parentheses.

$* * *$ statistically significant at the $1 \%$ level $* *$ statistically significant at the $5 \%$ level *statistically significant at the $10 \%$ level 
Table 5 The Effects on EFFICIENCY, REJECTION RATE, DOWNTIME of Team Membership:

Fixed Effect Estimates for Members with and without Education beyond High School

\begin{tabular}{|c|c|c|c|c|c|c|c|c|c|}
\hline \multirow{3}{*}{$\begin{array}{l}\text { Independent } \\
\text { Variable }\end{array}$} & \multicolumn{9}{|c|}{ Dependent Variable } \\
\hline & \multicolumn{3}{|c|}{ EFFICIENCY } & \multicolumn{3}{|c|}{\begin{tabular}{|l} 
REJECTION RATE \\
\end{tabular}} & \multicolumn{3}{|c|}{$\begin{array}{r}\text { DOWNTIME } \\
\end{array}$} \\
\hline & \begin{tabular}{|c|} 
Mean of \\
Independent \\
Variable \\
\end{tabular} & $(1)$ & $(2)$ & \begin{tabular}{|c|} 
Mean of \\
Independent \\
Variable \\
\end{tabular} & (3) & (4) & \begin{tabular}{|c|} 
Mean of \\
Independent \\
Variable \\
\end{tabular} & $(5)$ & (6) \\
\hline MORE EDUCATED MEMBER & 0.110 & $\begin{array}{c}3.941 * * * \\
(5.164) \\
\end{array}$ & \begin{tabular}{|c|}
$3.374 * * *$ \\
$(4.380)$ \\
\end{tabular} & 0.059 & \begin{tabular}{|c|}
$-0.694 * * *$ \\
$(6.895)$ \\
\end{tabular} & \begin{tabular}{|c|}
$-0.661 * * *$ \\
$(6.518)$ \\
\end{tabular} & 0.109 & $\begin{array}{c}0.211 * * * \\
(6.273) \\
\end{array}$ & $\begin{array}{c}0.162 * * * \\
(4.797) \\
\end{array}$ \\
\hline $\begin{array}{l}(\text { DAYS IN TEAM)* } \\
(\text { MORE EDUCATED MEMBER })\end{array}$ & 0.356 & $\begin{array}{c}-0.976^{* * * *} \\
(5.633)\end{array}$ & $\begin{array}{c}-0.872 * * * \\
(5.001) \\
\end{array}$ & 0.139 & \begin{tabular}{|c|}
$0.119 * * *$ \\
3.622
\end{tabular} & $\begin{array}{c}0.120 * * * \\
(3.670)\end{array}$ & 0.356 & $\begin{array}{c}-0.032 * * * \\
(4.128)\end{array}$ & $\begin{array}{c}-0.022 * * * \\
(2.905)\end{array}$ \\
\hline LESS EDUCATED MEMBER & 0.128 & $\begin{array}{c}3.098 * * * \\
(4.474) \\
\end{array}$ & $\begin{array}{c}2.856^{* * * *} \\
(4.117) \\
\end{array}$ & 0.110 & \begin{tabular}{|l|}
-0.048 \\
$(0.637)$ \\
\end{tabular} & $\begin{array}{l}-0.038 \\
(0.503) \\
\end{array}$ & 0.129 & $\begin{array}{c}0.146^{* * *} \\
(4.802) \\
\end{array}$ & $\begin{array}{c}0.126^{* * *} \\
(4.145) \\
\end{array}$ \\
\hline $\begin{array}{l}\text { (DAYS IN TEAM)* } \\
\text { (LESS EDUCATED MEMBER) }\end{array}$ & 0.335 & $\begin{array}{c}-1.048 * * * \\
(5.309) \\
\end{array}$ & $\begin{array}{c}-1.125 * * * \\
(5.687) \\
\end{array}$ & 0.267 & $\begin{array}{l}-0.054 * * \\
(2.246) \\
\end{array}$ & $\begin{array}{l}-0.046^{*} \\
(1.894) \\
\end{array}$ & 0.340 & $\begin{array}{l}0.015^{*} \\
1.762 \\
\end{array}$ & $\begin{array}{c}0.009 \\
(1.050) \\
\end{array}$ \\
\hline $\begin{array}{l}\text { Controlling for the tenure } \\
\text { of the worker and its square }\end{array}$ & & No & Yes & & No & Yes & & No & Yes \\
\hline $\mathrm{N}$ & 39351 & 39351 & 39351 & 21965 & 21965 & 21965 & 39340 & 39340 & 39340 \\
\hline Adjusted R-squared & & 0.371 & 0.371 & & 0.106 & 0.106 & & 0.252 & 0.254 \\
\hline
\end{tabular}

Source: All data provided by PARTS. Data are for 102 operators at PARTS during the period January 1, 1999 to November 30, 2001.

Notes:

1. MORE EDUCATED MEMBER $\mathrm{it}_{\mathrm{it}}$ is 1 if Worker $\mathrm{i}$ is a more educated team member in Time $\mathrm{t}$, and zero otherwise.

(See Table 1 for the definition of more educated members)

2. LESS EDUCATED MEMBER ${ }_{\mathrm{it}}$ is 1 if Worker $\mathrm{i}$ is a less educated team member in Time $\mathrm{t}$, and zero otherwise.

(See Table 1 for the definition of less educated members)

3. DAYS IN TEAM ${ }_{\mathrm{it}}=$ the number of days for which Worker $\mathrm{i}$ has been a team member at Time $\mathrm{t}$.

4. All models include individual fixed effects and monthly time dummy variables. Absolute values of $t$ statistics are in parentheses.

$* * *$ statistically significant at the $1 \%$ level ${ }^{* *}$ statistically significant at the $5 \%$ level *statistically significant at the $10 \%$ level 
Figure 1 Time Effects (EFFICIENCY) and the Number of Team Members: Jan. 1999-Nov. 2001

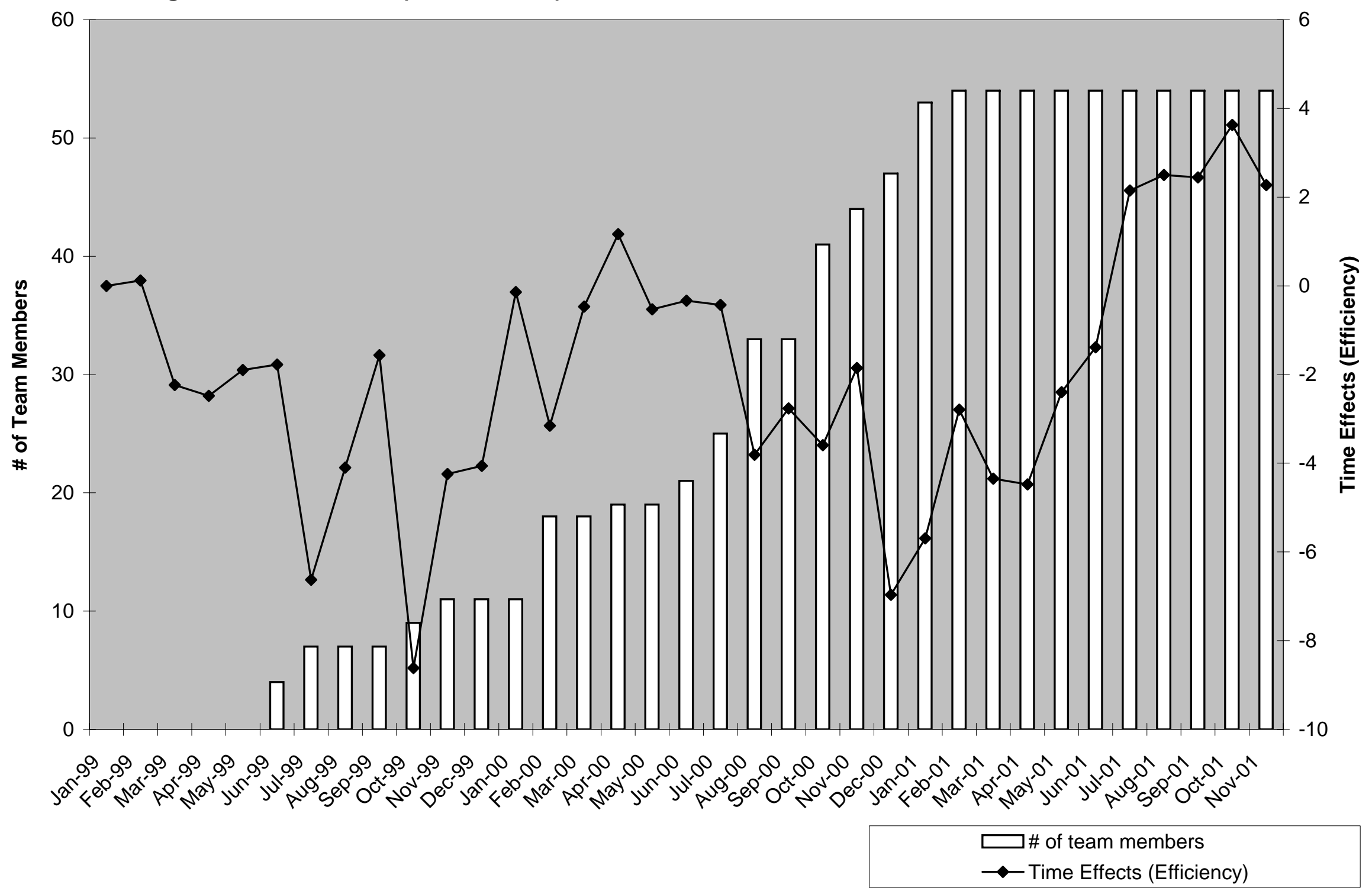


Figure 2 Time Effects (REJECTION RATE) and the Number of Team Members:

Jan. 1999-Nov. 2001

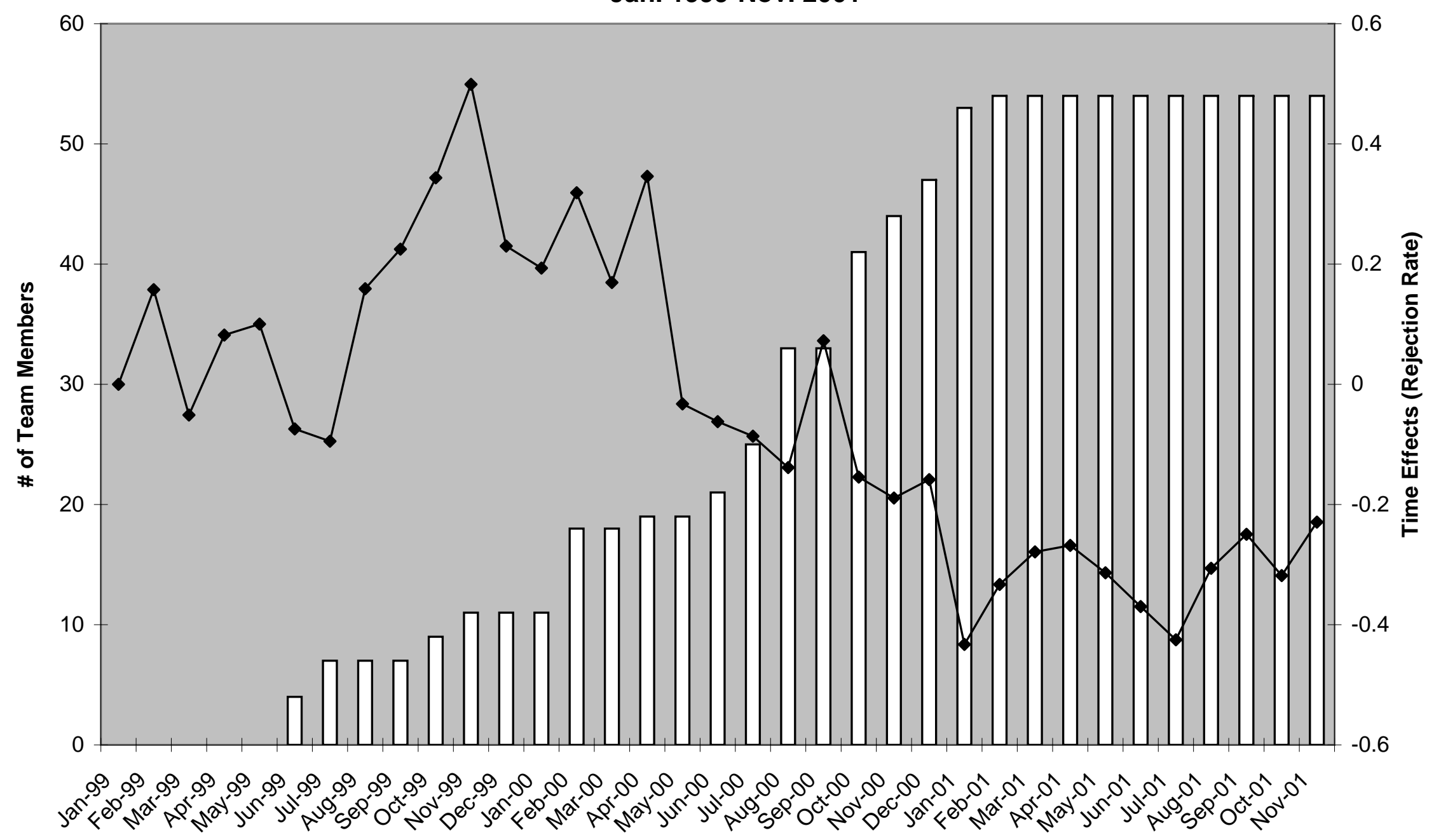

\# of team members

Time Effects (REJECTION RATE) 